\title{
UPSETS OF THE GASTROINTENESTINAL TRACT IN VICTIMS WITH A COMBINED TRAUMA IN CASE OF POLYTRAUMA
}

\author{
*V.O. Kryliuk, A.H. Iftodii, V.K. Hrodets'kyi
}

Abstract. The paper presents the results of a retrospective research of victims with a severe combined trauma of the organs of the abdominal cavity for the purpose of developing in them of the signs of gastrointestinal insufficiency. The case fatality rate among 365 victims made up 36,5\%. The most common manifestation of the gastrointestinal insufficiency in victims with a combined trauma of the organs of the abdominal cavity is the absence of peristalsis - 56,4 \% and the signs of intraabdominal hypertension $-43,2 \%$.

Key words: abdominal cavity trauma, victims, disorders of gastrointestinal tract.

*P.L. Shupyk National Medical Academy of Postgraduate Education (Kyiv) Bukovinian State Medical University (Chernivtsi)

Рецензент - проф. Р.І. Сидорчук
Buk. Med. Herald. - 2013. - Vol. 17, № 2 (66). - P. 65-69

Надійшла до редакції 18.03.2013 року

(c) В.О. Крилюк, А.Г. Іфтодій, В.К. Гродецький, 2013

УДК 616.716.4-089.843-031:616-77

Р.А. Левандовський

\section{БІОМЕХАНІЧНЕ ОБГРУНТУВАННЯ КІЛЬКОСТІ ІМПЛАНТАТІВ У МІЖМЕНТАЛЬНОМУ ПРОСТОРІ НИЖНЬОЇ ЩЕЛЕПИ ДЛЯ ФІКСАЦЇ̈ ОРТОПЕДИЧНОЇ АПАРАТУРИ}

Буковинський державний медичний університет, м. Чернівці

Приватна стоматологічна клініка д-ра Р. Левандовського, м. Коломия

\begin{abstract}
Резюме. Проведено біомеханічне обгрунтування розміщення і кількості імплантатів у міжментальному просторі нижньої щелепи для фіксації ортопедичної апаратури. Дослідження проведено на 54 пацієнтах віком від 41 до 86 років (23 чоловіки та 31 жінка) зі складною щелепно-лицевою патологією, яким у міжментальній ділянці беззубої нижньої щелепи було уведено 207 імплантатів, із яких: 187 одноетапових нерозбірних та 20 двохетапових розбірних. Біомеханічно доведено,
\end{abstract}

що повноцінне функціонування ортопедичної апаратури залежить від кількості опорних фіксуючих елементів, а кількість імплантатів та варіанти їх розміщення від конкретної клінічної ситуації.

Ключові слова: складна щелепно-лицева патологія, ортопедична апаратура, кількість і розміщення імплантатів, міжментальний простір нижньої щелепи, біомеханічне обгрунтування.
Вступ. Населення планети невпинно старіє, тому зростає частка людей з повною відсутністю зубів, зокрема на нижній щелепі (НЩ) [13]. У сучасній стоматології протезування на дентальних імплантатах є одним із основних та перевірених часом методів відновлення функції зубних рядів, що має прогнозовані віддалені результати $[8,12,19]$. Відомі різноманітні варіанти протезування при повній втраті зубів $[4,5]$. Але, зі збільшенням тривалості життя жителів планети, виникає потреба в нових концепціях підходу до ортопедичної реабілітації беззубих щелеп, а саме: допомога пацієнтам із тяжкими соматичними захворюваннями, які втратили всі природні зуби внаслідок онкологічних проблем [11].

Останнім часом при протезуванні беззубої НЩ на імплантатах стали особливо популярними і затребуваними, так звані умовно-знімні протези (УЗП) $[11,12]$, покривні протези (ПП) $[7,2]$ або перекриваючі [13]. Для демонтажу УЗП потрібен додатковий інструмент (наприклад, викрутка), а це повинен зробити лікар. У тяжких соматичних хворих, при повній адентії на нижній щелепі, застосовують протези, що демонтуються самим пацієнтом або обслуговуючим персоналом за допомогою індивідуальних ключів (рис. 1) [16].

Як же провести грань між протезом 3 акриловим базисом зі штучними яснами та штучними акриловими зубами, укріпленого на імплантатах за допомогою гвинтів, називаючи його умовнознімним (УЗ), та протезом на балці (покривний, перекриваючий (ПП), який фіксується тими ж гвинтами, а сам протез знімається тільки 3 допомогою індивідуального ключа разом із балкою або без неї, шляхом індивідуального його виведення. Яка тоді різниця між викруткою для демонтажу УЗП без руйнування його та індивідуальним ключем, для зняття запропонованої нами конструкції протеза на імплантатах у міжментальній ділянці НЩ [16]. Тобто, гра слів, термінологій, неточність перекладів, навіть із авторитетних джерел, наявність у різних модифікаціях ОА елементів УЗ та ПП призводять до ситуацій, коли про одну і ту ж саму конструкцію тлумачать різні 
школи по-різному. Тобто, на практиці виготовляється величезна кількість різноманітної ОА опорою, якої $є$ імплантати, уведені на НЩ у міжментальний простір [13]. Має місце дискусія про конструкції, що мають переваги в даних конкретних умовах, а нерідко це просто конкурентна боротьба між виробниками. 3 точки зору біомеханіки в міжментальній ділянці нижньої щелепи при певній кількості імплантатів можливо відновити цілісність зубного ряду за допомогою як ПП, так і УЗП в окремому, конкретному випадку. То яка між ними різниця, який є кращий чи ефективніший? Різниця полягає в тому, що перший - укріплений на імплантатах за допомогою гвинтів, а другий - за допомогою балки, яка також зафіксована до імплантатів (цемент, гвинти), найчастіше гвинтами [13], тому об'єднаємо їх у даній роботі під назвою ортопедична апаратура (ОА). Однак, незважаючи на популярність цих конструкцій, біомеханічний аналіз, побудований на базі як даних комп'ютерної томографії (КТ), так і методу кінцевих елементів (МКЕ) мало описаний. Такий аналіз частково на основі загальних принципів біомеханіки в стоматології $[15,20]$ викладено в роботах $[1,21,22]$.

Мета дослідження. Проаналізувати загальні принципи біомеханіки протезів на імплантатах, їх кількість та конфігурацію розміщення в міжментальній ділянці нижньої щелепи, надання практичних рекомендацій щодо їх застосування.

Матеріал і методи. Для дослідження відібрано 54 пацієнти (31 жінка та 23 чоловіки) віком від 41 до 86 років зі складною щелепно-лицевою патологією (СЩЛП): значна атрофія щелеп різного генезу, стан після видалення злоякісних та доброякісних пухлин, травм, яким було уведено 207 імплантатів, фірми "RADIX", із них 179 одноетапових нерозбірних імплантатів RADIXGIMLET-DM у 47 пацієнтів (29 жінок та 18 чоловіків). Крім того, були уведені в міжментальній ділянці беззубої НЩ у п'яти чоловіків по чотири двохетапових розбірних імплантати RADIXGIMLET-LLS, чотири імплантати одноетапових нерозбірних WITAPLANT-VKm та три т. з. цвяхи LINKOV, а також суцільні одноетапові (у двох жінок по чотири). Жодному з вказаних пацієнтів не проводилося кісткових пластик, аугментації кістки внаслідок різного роду протипоказань або відмови самих пацієнтів, також їм не було відмовлено в проведенні самої операції імплантації через СЩЛП.

Для врахування місця розміщення і кількості імплантатів залежно від клінічних умов до протезування та доведення біомеханічної доцільності використані методи кінцевих елементів та аналітичної математики.

Результати дослідження та їх обговорення. 1. Загальні принципи біомеханіки ортопедичноі апаратури (OA) на імплантатах. Відомо, що людина за різних вихідних умов у нормі та патології за допомогою жувальних м'язів та природних зубів при різновекторних навантаженнях може створити зусилля від 30 до 640 н/см² [13]. Тому, з точки зору математики, інколи виникають нереальні для виконання завдання, які б мали достовірні результати. Так, у техніці розрахувати задані параметри набагато легше, бо маємо справу зі стабільними параметрами (маса, швидкість, гравітація і т.п.). В основі ж біомеханічного аналізу зубощелепної системи, як у нормі, так і при будь-яких патологічних станах, слід враховувати не тільки наявності елементів, які використовуються при реконструкції зубного ряду (покривні, умовно-знімні протези, імплантати, мостоподібні протези і т. ін.), а також міцність і жорсткість конструкції [20]. Всі ці навантаження при певній кількості імплантатів будуть передаватися та перерозподілятися, через конструкції, на з'єднання двох, трьох, чотирьох або п'яти імплантатів, а вже через них - на щелепну кістку. Ці умови взаємно пов'язують з навантаженням - розрахункові моделі (конструкція ортопедичної апаратури) аналізованих елементів та властивості кісткової тканини в ділянці операції (конструкційних матеріалів). Тому, представивши ці умови у вигляді трикутника, можна визначити будь-яку з вершин його при відомих значеннях двох інших (рис. 2).

Отже, необхідно знати максимальні та мінімальні жувальні навантаження для конкретного пацієнта в нормі, за наявності захворювання i після реконструкції, наприклад, встановлення ортопедичної апаратури, імплантату, елемента фіксації і т. ін.

Розрахункова модель (конструкція ортопедичної апаратури, анатомія міжментальної ділянки)

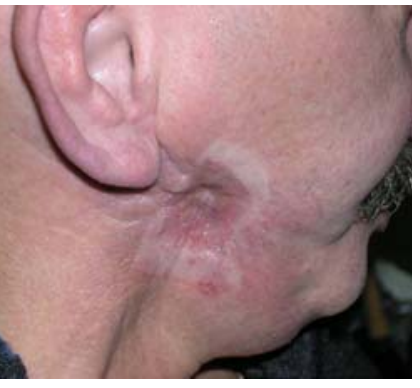

a

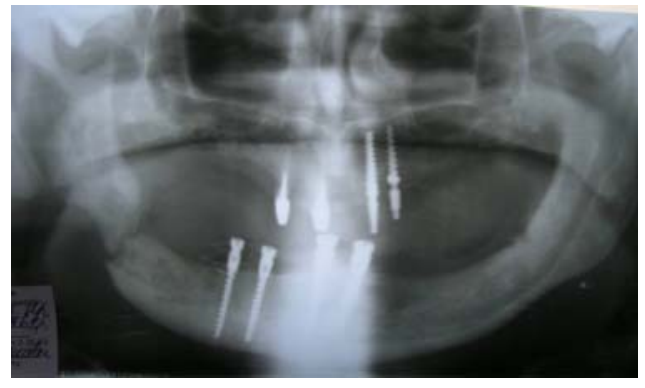

6

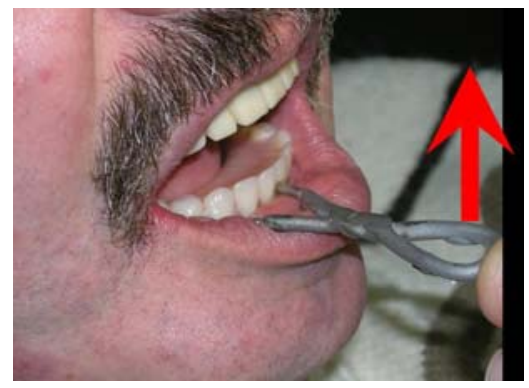

B

Рис. 1. Хворий А., 47 p. С-r слизової оболонки ретромолярної ділянки нижньої щелепи справа: а) - стан через 4 роки (хронічний постпроменевий остеомієліт, нориця); б) - чотири імплантати в міжментальному просторі нижньої щелепи; в) - індивідуальний ключ для зняття ОА через обмежене відкривання рота та несправжній суглоб у ділянці кута нижньої щелепи 


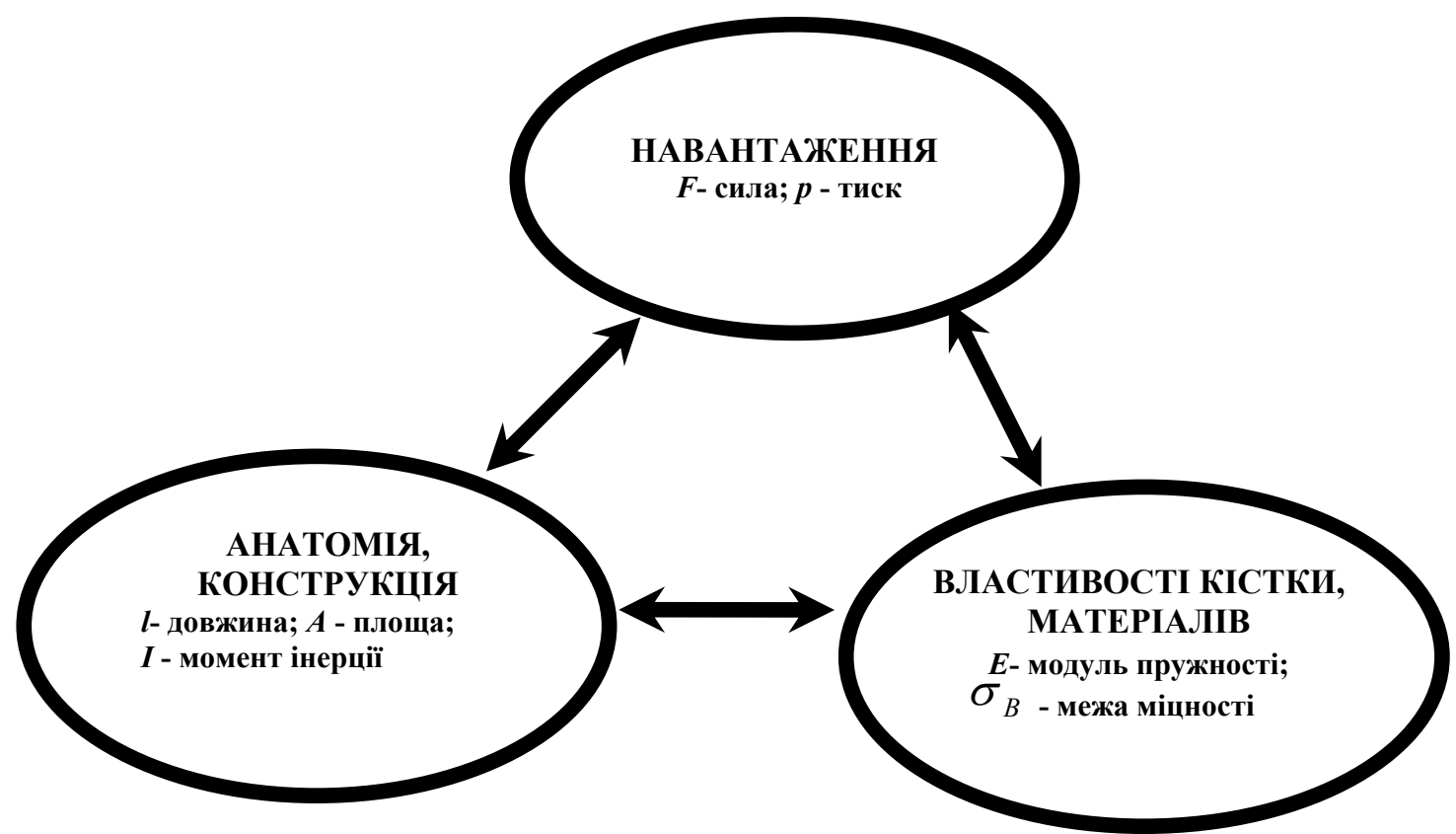

Рис. 2. Умови міцності, як основа біомеханічного аналізу

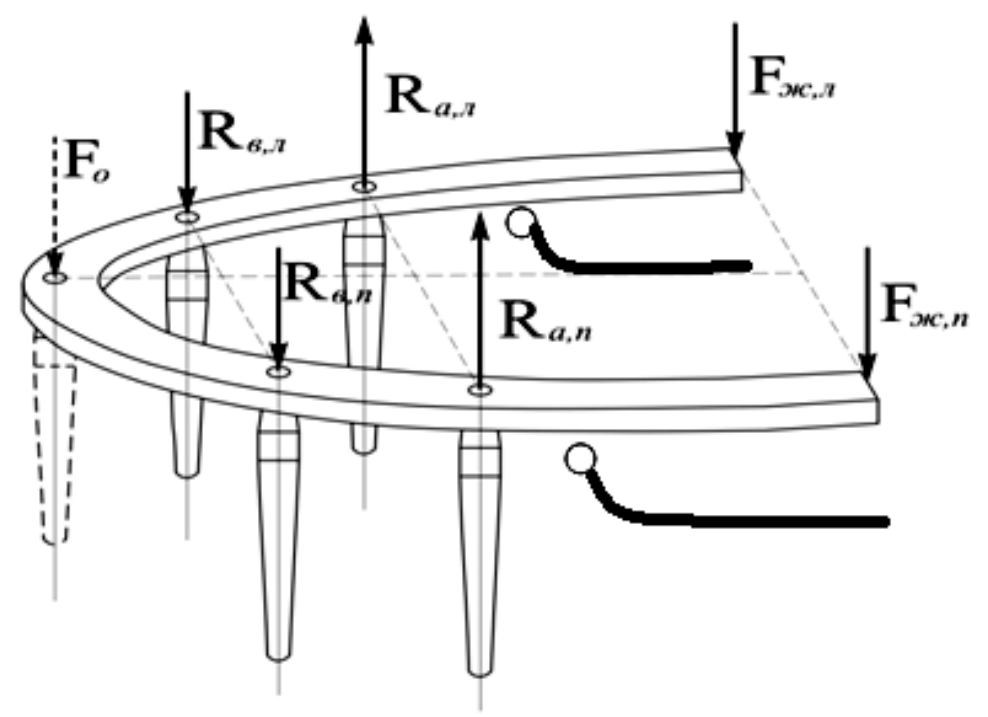

Рис. 3. Розрахункова схема можливого розміщення імплантатів у міжментальному просторі нижньої щелепи для фіксації ортопедичної апаратури. Загальний вигляд FM - ментальний отвір

аналізованих елементів - це власне і $є$ побудова моделі та іiі раціоналізація відповідно до поставлених завдань дослідження. Завжди слід мати на увазі, що модель може мати тільки ті результати, які передбачені в іiі функціонуванні. Далі під конструкцією ми будемо розуміти об'єкт дослідження, яким може бути і щелепа, і зуб, і різноманітна ортопедична апаратура, i імплантат будьякого типу.

Властивості кісткової тканини. Якщо ми не знаємо кількісних характеристик міцності кістки конкретного пацієнта, то всі наші міркування будуть носити якісний характер - потрібно більше, потрібно менше. Методика визначення механічних характеристик кісткових і м'яких тканин докладно розглянута в роботах $[20,22]$.

Сила, жорсткість $і$ піддатливість пружної системи взаємопов'язані. Жорсткість або піддатливість будь-якої пружної системи може характе- ризуватися різними показниками, залежності від напрямку і типу навантаження, а також від прийнятої розрахункової схеми (моделі) [21]. Відзначимо загальну закономірність при обчисленні жорсткості системи. Так, при розтягуванні (стиску) жорсткість лінійно залежить від жорсткості стрижня на розтяг (стиск) ЕА і обернено пропорційна його довжині 1. Навпаки, при вигині жорсткість лінійно залежить від жорсткості елемента (балки) на вигин ЕJ і обернено пропорційна його довжині 1 у кубі.

Таким чином, зміна довжини при вигині впливає більш суттєво, ніж збільшення площі поперечного перерізу, яка зв'язана з діями лікаря на будь-якому етапі лікування. Якщо порівнювати жорсткість титану та кортикальної щелепної кістки, то навіть найеластичніший сплав титану має у два рази більшу жорсткість, ніж середньостатистична кортикальна пластинка щелепної 
кістки людини [8]. 3 практики відомо, що перелом тіла імплантату можливий, але ймовірніше послаблення кістки біля нього як наслідок ятрогенної хірургічної або ортопедичної помилки .

Піддатливість елемента конструкиії - величина зворотна жорсткості конструкції (системи). Піддатливість будь-якої біоконструкції $є$ відносним показником, що характеризує здатність чинити опір зовнішнім навантаженням незалежно від їхньої конкретної величини. Показник піддатливості може бути вирахуваний аналітично, бо математично обчислюється за формулами, які включають основні конструктивні параметри. Це $\epsilon$ властивість конструкції. Він може бути визначений і експериментально, якщо виміряти переміщення в системі та розділити на величину навантаження, що викликає це переміщення (піддатливість - величина, зворотна жорсткості, має розмірність мм/Н). Піддатливість - це переміщення в системі при силі, яка дорівнює одиниці. Для імплантату або будь-якої ортопедичної апаратури коефіцієнт піддатливості можна уніфікувати під кожен тип конструкції, що значно полегшить підбір необхідного типу ортопедичної апаратури в кожному конкретному випадку.

Умова жорсткості. Зазвичай використовується при аналізі переміщень і формулюється у вигляді рівняння, в якому переміщення, пропорційне діючому навантаженню, визначається за аналітичними формулами або на основі аналізу кінцево-елементних моделей [20, 21], порівнюється 3 допустимим переміщенням, визначеним нормативними документами або на практиці досвідом лікаря.

2. Попередній аналіз біомеханіки ортопедичної апаратури(ОА), укріпленої на дентальних імплантатах у міжментальній ділянизі НЩ. Попередній системний біомеханічний аналіз проводили на основі основних залежностей механіки, викладених у роботах $[8,10]$. Розрахункова схема (ОА), використовувана для попереднього аналізу, представлена на рис. 3 .

3 позицій механіки (опору матеріалів) корпус (ОА) являє собою складову балку, що включає металеву балку, каркас і штучні ясна, вигнуту за профілем НЩ з повною адентією, що спирається на імплантати (проміжні опори) і в консольних частинах на слизову оболонку альвеолярних відростків (м'яка складова).

У роботі [20] доведено, що біомеханіка процесів відкушування і однобічного жування істотно відрізняється одна від одної. На рис.3, з метою спрощення, сили і реакції, що виникають при обох процесах, умовно поєднані, але сила, що виникає при відкушуванні $F_{\text {o, }}$ як і імплантат, встановлений у центрі фронтальної частини НЩ, показані пунктирно.

Довговічність всієї системи такого типу, характер іiї поведінки на всіх стадіях життєвого циклу, залежить від практичного вирішення питань фіксації і стабілізації. Оскільки однозначне розуміння цих термінів у стоматологів і механіків неоднозначне, то потрібно детальніше його розглянути [3, 20] використовуючи визначення, наведені в [18]. 3 позицій механіки конструкцію ОА можна і потрібно розглядати як тверде чужорідне тіло, при розгляді питань його фіксації, і як пружне тіло, при розгляді питань його стабілізації.

2.1. Особливості фіксації ортопедичної апаратури (OA). Стосовно до біомеханіки термін «фіксація» можна вважати синонімом поняття «закріплення» або «нерухомість» твердого тіла в просторі. Фіксація (від лат. Fixus - міцний, закріплений) (фіксування), закріплення чогонебудь у певному положенні [18]. Сама ОА, як тверде тіло в просторі, має шість ступенів свободи - три поступальних і три обертальних[20]. Зафіксувати або жорстко закріпити таке тіло в просторі - це значить позбавити його всіх цих шести ступенів свободи, тобто зробити його нерухомим. Враховуючи, що штучні ясна спеціально профілюються по поверхні альвеолярного гребеня (НЩ), то найбільш імовірними видами руху корпуса (OА) можуть бути два - рух вгору-вниз, за рахунок відриву корпуса від альвеолярного гребеня, і обертання (зсув) у горизонтальній площині.

3 наведених міркувань можна зробити важливий для практики висновок. Для фіксації ОА в просторі (беззуба НЩ) достатньо двох імплантатів, відстань між якими повинна бути максимальною. Цей висновок теоретичний, який отримано за умови, що імплантати жорстко закріплені в кістковій тканині. На практиці й імплантати, і корпус ОА мають кінцеву жорсткість, тому збільшення кількості імплантатів підвищує надійність фіксації ОА при заданому навантаженні.

2.2. Особливості стабілізації ОА. Дослідження стабілізації такої складної конструкції, яка схематично показана на рис.1, можна проводити як поелементно, так і в цілому, використовуючи дидактичний принцип «від простого до складного» [20]. Як і в попередньому розділі, розглянемо спочатку існуючі в літературі визначення терміну стабілізація. Стабілізація (від лат. Stabilis - стійкий), усталення, приведення в постійне стійкий стан або підтримання цього стану, а також сам стан стійкості, сталості [18]. Стабілізація ОА на імплантатах визначається можливістю пружного деформування корпуса ОА, голівок імплантатів, їх опорних елементів, які залежать від раціонального розташування вузлів фіксації, їх жорсткості, розмірів поперечного перерізу елементів і голівки (жорсткістю на згин), лінійних розмірів конструкції та ступеня остеоінтеграції імплантатів з кістковим ложем.

При поелементному аналізі, крім поділу біомеханіки процесів відкушування і однобічного жування, у [20] розглянута (ОА) як при вигляді спереду (фронтальний переріз), так і при вигляді збоку (сагітальній переріз). Використовуючи знову ж таки дидактичний принцип «від простого до складного» [20], у [21] послідовно розглянуто ОА 3 опорою на 2, 3, 4 і 5 імплантатів. При цьому 
аналізі в [21] принципово не пропонуються готові рецепти, обговорюючи тільки функціональні взаємозв'язки та припускаючи, що в кожному клінічному випадку повинен проводитись «глибокий біомеханічний аналіз».

Тому, для розрахунків, за наведеними залежностями, необхідне знання цілого ряду вихідних даних як геометричних (анатомічних), так і механічних параметрів, серед яких особливе значення мають механічні характеристики м'яких і кісткових тканин, особливо в зонах розташування опорних елементів.

Дослідження ОА з 2, 3, 4 і 5 опорними імплантатами в процесі відкушування їжі і жування дозволяє констатувати наступне.

При застосуванні двох імплантатів. Хороша фіксація забезпечується, особливо при великій відстані між імплантатами і їх достатній жорсткості при сприйнятті моментних навантажень. У процесі відкушування іжі і великій відстані між імплантатами можливий значний прогин балки до контакту зі слизовою оболонкою та іiі циклічним травмуванням при ослабленні цих імплантатів у кістці. При V-подібній дузі і великому виступу вперед імплантати будуть навантажені моментом, який діє як «вивертаючий», і відриває дистальну частину (ОА) від ясен. У процесі пережовування їі імплантати будуть навантажуватися «вивертаючим» моментом при великій піддатливості слизової оболонки. На наш погляд, кріплення ОА на двох імплантатах не $\epsilon$ кращим варіантом з точки зору біомеханіки, бо має обмежене показання для застосування тільки при трапецієподібній формі фронтальної частини НЩ та короткому міжментальному просторі, а крім того, у такому випадку, ОА повинна бути тільки знімна. Позиційно вони будуть розміщуватися найчастіше на місці 33-го та 43-го зубів. По відношенню до кортикальної кістки цілком можливе бікортикальне та трескортикальне позиціонування [9].

Варіант використання трьох імплантатів. Фіксація забезпечується краще, ніж при двох імплантатах. У процесі відкушування їкі центральний імплантат, особливо встановлений бікортикально, трескортикально, панкортикально [9] (у цьому місці завжди є умови для такої фіксації), буде сприймати майже всі навантаження. Справедливо виникає питання щодо міцності з'єднання. Збільшення відстані між центральним і бічними імплантатами, настільки це можливо дозволить перерозподілити навантаження більш рівномірно, особливо при достатній згинаючій властивості жорсткості балки. Ще одне питання, що виникає, це косметика протеза. Тому імплантат доводиться зміщувати вправо або вліво від середньої лінії НЩ, а це змінить біомеханічні параметри правого і лівого боку протеза, що також не $\epsilon$ фатальним, бо з практики відомо, що більшість людей мають звичний («улюблений») бік жування-однобічний тип жування. У процесі

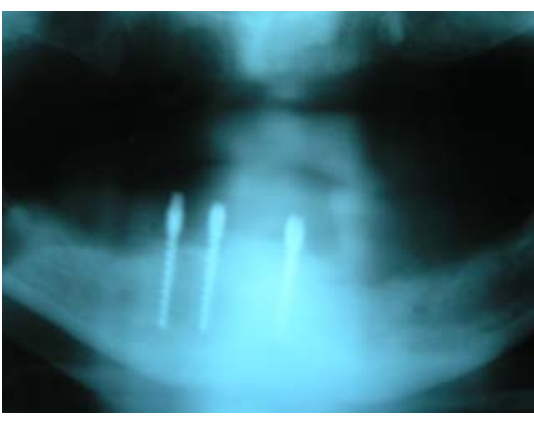

a

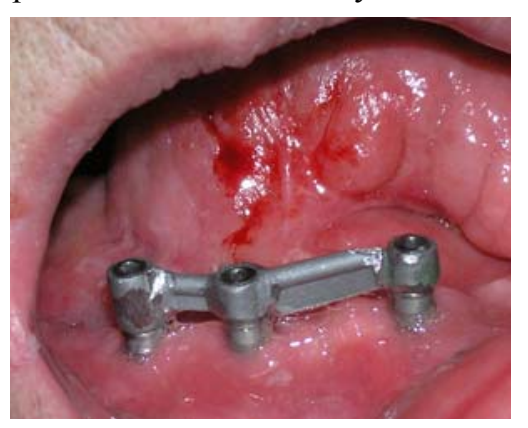

6

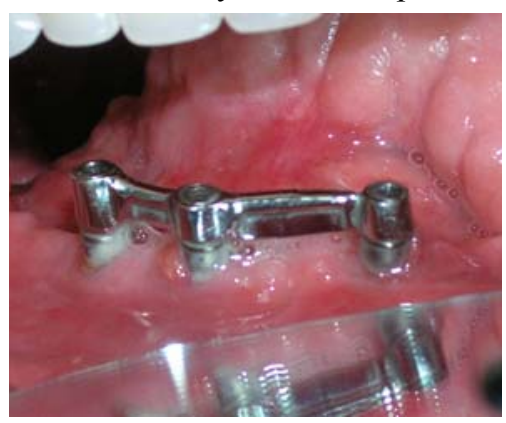

Рис. 4. Хворий М., 60p. Три імплантати в міжментальному відділі нижньої щелепи після резекції 2/3 язика 3 приводу раку слизової оболонки бокової поверхні язика: а) - три імплантати в правій половині нижньої щелепи (через тяжкий стан хворого під час операції було змінено план оперативного втручання. Замість п'яти імплантатів у міжментальній ділянці імплантовано тільки три; б) - балка Румпеля; в) - термін експлуатації ОА до 1 року через неправильне розміщення імплантатів

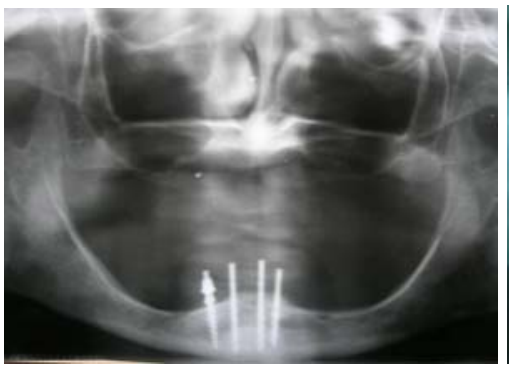

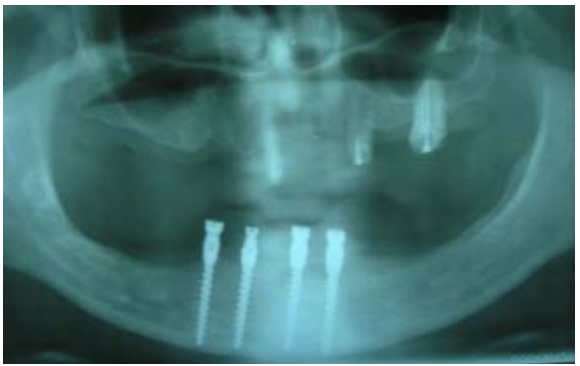

6

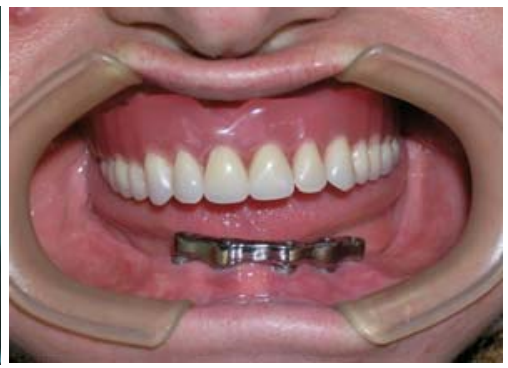

B

Рис. 5. Пац. В., 84 р. а - рівномірна атрофія 1-й тип за Келлером, бікортикальна фіксація всіх чотирьох імплантатів, фіксація ОА на цемент; б) - Пац 53 р, бікортикальна фіксація імплантатів, ОА на гвинтах; в) - балка для фіксації ОА на п'яти імплантатах 
пережовування їжі, якщо всі три імплантати розташовані в одному ряду (що практично неможливо), вони будуть навантажуватися «вивертаючим» моментом залежно від піддатливості слизової оболонки тільки з дистальної зони.

При збільшенні відстані між центральним i бічними імплантатами в сагітальній площині згинальний момент, переданий дистально витягнутою частиною ОА, буде сприйматися реакціями в імплантатах - ближні (бічні) будуть втискатися в кістку і ясна, а дальні (центральні) - відповідно «вириватися» 3 кістки і ясен. Тому, ми вважаємо, що кріплення ОА на трьох імплантатах показано при V-подібній формі фронтальної частини НЩ. Можливо використання незнімної конструкції 3 дистальним витяганням, але, як показує час, вона не може тривало повноцінно функціонувати (рис. 4).

Варіант фіксачї на чотирьох імплантатах. Фіксація забезпечується досить добре. У процесі відкушування їжі два центральних імплантати, будуть сприймати майже все навантаження. Оптимальні відстані між центральними і бічними імплантатами дозволить перерозподілити навантаження більш рівномірно, особливо при достатній згинальній жорсткості балки. У процесі пережовування їжі, якщо всі чотири імплантати розташовані в одному ряду (що неможливо через анатомію НЩ), вони будуть навантажуватися «вивертатаючим» моментом залежно від піддатливості слизової оболонки. При збільшенні відстані між рядами імплантататів у сагітальній площині згинальний момент, переданий дистально витягнутою частиною ОА, буде сприйматися реакціями в імплантатах - ближні (бічні) будуть втискатися в кістку і ясна, а дальні (центральні) відповідно «вириватися» 3 кістки і ясен.

Отримала поширення трапецієподібна форма розташування імплантатів, за умови, що відстань між крайніми імплантатами і рядами імплантатів буде максимально можлива в кожного конкретного пацієнта. Тому, ми вважаємо, що це найбільш оптимальний варіант, який дозволяє рівномірно розподілити жувальне навантаження між імплантатами і слизовою оболонкою, включаючи ОА зафіксовану на цемент (рис. 5).

При такому розташуванні імплантатів легше відкоригувати ортопедично тип жування. Передні типи жування піддаються корекції легше. Крім того, практика в багатьох країнах світу показала тривале функціонування ОА на чотирьох імплантатах, розміщених у міжментальній ділянці НЩ $[13,21]$. Бо при правильно виготовленій ОА пацієнти переходять до збалансованого почергового паралельного латерального жування. У пацієнтів 3 обтяженим в анамнезі правобічним або лівобічним типом пережовування їжі корекція проходить все одно набагато триваліше в часі через індивідуальне біомеханічне звикання протягом всього життя. Щодо позиції імплантатів по відношенню до кортикальної кістки, то всі чотири імплантати можливо закріпити мінімум бікортикально завжди, а трескортикально майже завжди.
Фіксація на п'яти імплантатах. Ця конструктивна схема поєднує в собі всі особливості вищезгаданих варіантів фіксування на трьох і чотирьох імплантатах. Так, при вузькій фронтальній ділянці НЩ, міжментальними отворами, при уведенні п'яти імплантатів кровопостачання оточуючих імплантат тканин може бути порушено. А при виникаючій необов'язковій надлишковій міцності і жорсткості опорних елементів можливе вимушене порушення і косметики ОА.

Тому, така схема розташування імплантатів може бути рекомендована тільки в конкретних клінічних випадках. Наприклад, при дуже широкій фронтальній частині НЩ, гіперстенічній будові щелепно-лицевої ділянки, та за наявності парафункції в анамнезі тощо (рис. 5в).

\section{Висновок}

Отже, біомеханічно доведено, що повноцінне функціонування ортопедичної апаратури залежить від кількості опорних фіксуючих елементів, a їх кількість і варіанти розміщення від конкретної клінічної ситуації. Найоптимальніша кількість та конфігурація розміщення чотирьох імплантатів у міжментальній ділянці є трапецієподібною.

Перспективи подальших досліджень. Планується проведення порівняльного системного біомеханічного аналізу навантаження імплантатів залежно від геометрії їх розташування, який дозволить визначити зусилля у системі і може бути основою для більш глибокого аналізу в використанні сучасних комп'ютерних технологій.

\section{Література}

1. Аналіз анатомо-топографічних умов для імплантації з використанням комплексу MIMICS-SolidWorks / [А.М. Чуйко, Р.А. Левандовський, О.Б. Бєліков, М.М. Угрин] // Нов. стоматол. - 2012. - № 3. - С. 66-70.

2. Біомеханіка покривних протезів з опорою на імплантати / [3.М. Хекманн, Й.Й. Лінке, В. Вінтер, Х.-П. Вебер] // Нов. стоматол. - 2003. - № 2. - С. 9-14.

3. Глоссарий основных понятий, терминов, определений и зависимостей применительно к челюстно-лицевой хирургии и стоматологии / А.Н. Чуйко, Р.А. Левандовский, А.Б. Беликов [и др.] // Бук. мед. вісник. - 2012. T. 16, № 2 (62). - С. 201-212.

4. Деякі аспекти клінічних і лабораторних етепів виготовлення повних знімних протезів при несприятливих умовах до протезування / За ред. проф. О.Б. Бєлікова / О.Б. Бєліков, Р.А. Левандовський, В.Д. Шуклін [та ін.]: Навчальний посібник. - Чернівці - Полтава Івано-Франківськ, 2012. - 240 с.

5. Добровольская О.В. Варианты съемного протезирования с помощью имплантатов при полной адентии / О.В. Добровольская // Укр. стоматол. альманах. 2008. - № 3. - С. 5-7.

6. Добровольська О.В. Клінічна і функціональна оцінка замісних ортопедичних конструкцій з опорою на імплантати при повній відсутності зубів на нижній щелепі: автореф. дис. на здобуття вчен. ступ. к. м. н. 14.00.22-Стоматологія / О.В. Добровольська. - Харків, 2012. $-20 \mathrm{c}$

7. Застосування балкових систем кріплення при лікуванні хворих з дефектами зубних рядів покривними протезами / В.Ф. Макєєв, Н.Р. Ключковська, П.В. Щерба [та ін.] // Современ. стоматол. - 2008. - № 4. C. 129-133. 
8. Идэ Стефан. Секреты базальной имплантологии / Идэ Стефан, Идэ Антонина // The International Implant Fondation. - Мюнхен, Германия, 2011. - 358 с.

9. Левандовський Р.А. Види кортикальної фіксації в дентальній імплантації / Р.А. Левандовський: матеріали V Україньського Міжнародного конгресу [«Стоматологічна імплантація.Остеоінтеграція»], (2728 квітня 2012), Київ. - К., 2012. -.С.174-176.

10. Левандовський Р.А. Інтелектуальні зубні протези / P.А. Левандовський: матеріали V Українського Міжнародного конгресу [«Стоматологічна імплантація. Остеоінтеграція»], (27-28 квітня 2012), Київ. - К., 2012. - С. 278-279.

11. Левандовський Р.А. Психологічні аспекти ортопедичної реабілітації пацієнтів 3 локалізацією злоякісних пухлин в щелепно-лицевій ділянці, зокрема на верхній щелепі / Р.А. Левандовський: матеріали Міжнародної науково-практичної конференції [«Теоретичні та практичні аспекти розвитку сучасної медицини»]. 2012, Львів (21-22 вересня). - С. 16-20.

12. Маланчук В.А. Непосредственная дентальная имплантация / В.А. Маланчук, Э.А. Маммадов. - К., 2008. $154 \mathrm{c}$.

13. Миш К.Е. Ортопедическое лечение с опорой на дентальные имплантаты / Карл Е. Миш; пер.с англ. - М.: Рид Элсивер, 2010. - 616 с.

14. Неспрядько В.П. Дентальна імплантологія. Основи теорії та практики / В.П. Неспрядько, П.В. Куц. - Харків: ВПП «Контраст», 2009. - 292 с.

15. Об особенностях биомеханики мостовидных протезов в зависимости от состояния опорных зубов и имплан- татов разных типов / [А.Н. Чуйко, О.Н. Суров, И.А. Шинчуковский, Р.А. Левандовский] // Укр. стоматол. альманах. - 2011. - № 4. - С. 60-66.

16. Патент України № 90946 С2, МПК А61С 3/00 Ключ для зняття часткового знімного протеза індивідуального користування / Левандовський Р.А. - опубл. 10.06.2010, Бюл. 11.

17. Параскевич В.Л. Дентальная имплантология: Основы теории и практики: Науч.-практ. пособие / В.Л. Параскевич. - Мн.: ООО «Юнипресс», 2001. - 368 с.

18. Советский энциклопедический словарь / Гл. ред. А.М. Прохоров - изд. 4-е. - М.: Сов. энциклопедия, 1987. $-1600 \mathrm{c}$.

19. Угрин М.М. Експериментальна та клінічна оцінка застосування дентальних імплантатів власної конструкції: автореф. дис. на здобуття вчен. ступ. к. мед. н. 14.00.22 “Стоматологія” / Угрин М.М. - Львів, 2007. $20 \mathrm{c.}$

20. Чуйко А.Н. Биомеханика в стоматологии / А.Н. Чуйко, И.А. Шинчуковский: Монография. - Х.: Изд-во «Форт». 2010. - 516 с.

21. Чуйко А.Н. Некоторые аспекты биомеханики условносъемных протезов на имплантатах / А.Н. Чуйко, Р.А. Левандовский // Ортопедия, травматол. и протезир. - 2012. - № 3. - С. 84-94.

22. Особливості підбору імплантатів 3 використанням комплексу MIMICS-ANSYS / [А.М. Чуйко, Р.А. Левандовський, О.Б. Бєліков, М.М. Угрин] // Нов. стоматол. - 2013. - № 1. - С. 50-55.

\section{БИОМЕХАНИЧЕСКОЕ ОБОСНОВАНИЕ КОЛИЧЕСТВА ИМПЛАНТАТОВ В МЕЖМЕНТАЛЬНОМ ПРОСТРАНСТВЕ НИЖНЕЙ ЧЕЛЮСТИ ДЛЯ ФИКСАЦИИ ОРТОПЕДИЧЕСКОЙ АППАРАТУРЫ}

\section{Р.А. Левандовский}

Резюме. Проведено биомеханическое обоснование количества имплантатов и их размещения в межментальном пространстве нижней челюсти для фиксации ортопедической аппаратуры. Исследование проведено на 54 пациентах в возрасте от 41 до 86 лет (23 мужчины и 31 женщина) со сложной челюстно-лицевой патологией, которым в межментальной области беззубой нижней челюсти было введено 207 имплантатов, из которых: 187 одноэтапных неразборных и 20 двухэтапных разборных. Биомеханически доказано, что полноценное функционирование ортопедической аппаратуры зависит от количества опорных фиксирующих элементов, а количество имплантатов и варианты их размещения от конкретной клинической ситуации.

Ключевые слова: сложная челюстно-лицевая патология, ортопедическая аппаратура, количество и размещение имплантатов, межментальное пространство нижней челюсти, биомеханическое обоснование

\section{BIOCHEMICAL SUBSTANTIATION OF THE NUMBER OF IMPLANTS IN THE MANDIBULAR INTERMENTAL SPACE FOR FIXING AN ORTHOPEDIC DEVICE}

\section{R.A. Levandovskyi}

Abstract. A biochemical substantiation of the placement and the number of implants in the mandibular intermental space for orthopedic fixation apparatus has been carried out. The study has been perfomed on 54 patients aged from 41 to 86 year(23 men and 31 women) with complex maxillofacial pathology who were introduced into the edentulous mandible 207 implants of wich 187 being single-stage uncollapsible and 20 being two-stage collapsible ones. It has been corroborated biochemically that an adequate functioning of the orthopedic apparatus depends on the number of abutment fixation elements, whereas the number of implants and variants of their placement plants upon a specific clinical situation.

Key words: complex maxillofacial pathology, orthopedic equipment, number and placement of implants, mandibular intermental space, biochemical substantiation.

Bukovinian State Medical University (Chernivtsi) Private Dental Clinic of Doctor R. Levandovskyi (Kolomyia)

Рецензент - доц. Н.Б. Кузняк

Buk. Med. Herald. - 2013. - Vol. 17, № 2 (66). - P. 69-75

Надійшла до редакції 08.04.2013 року

(C) Р.А. Левандовський, 2013 